\title{
Особливості модернізації гідро-пневматичного висівного апарату
}

\author{
Є.Я. Прасолов, Т.Ю. Рижкова, К.С. Величко \\ Полтавська державна аграрна академія (м. Полтава, Україна)
}

\begin{abstract}
Відомі конструкції гідравлічних та пневматичних висівних апаратів призводять до травмування насіння та їх паростків під час висіву. У модернізовану гідро-пневмосівалку пропонується вбудувати пристрої для покращення якості висіву насіння. До неї включено систему для знезараження насіння, пристрій для обробки насіння випромінюванням надвисокої частоти, пристрій для підрахунку кількості листочків пророщеної культури та підрахунку кількості насінин. Модернізовано конструкцію сошників, які забезпечують рівномірність висіву пророщеного насіння гідро-пневматичним способом.

Досліджувались фрізико-механічні властивості насіння овочів. Показано, що коефіцієнт тертя насіння з робочою поверхнею ложки та стінками насіннєвого ящика й інших допоміжних органів впливають на якість висіву насіння, кількість пропусків і пошкодження ростків в процесі висіву. Визначено, що найменше тертя насіння з робочими поверхнями у матеріалів ПВХ або фторопласт. Значне зниження коефіцієнту тертя при використанні пророщеного насіння у якості висівного матеріалу, де поліпшення якості висіву пророщеного насіння в порівнянні з непророщеним становить в середньому 48 \%. Використання запропонованої водо-насіннєвої рідини, якою змочують насіння в процесі висіву, підвищує якість затягування ложкою насіння. Це дозволяє переорієнтувати насіння в ложці та забезпечити його надійну фіксацію.

За трьома фракторами визначені оптимальні параметри роботи гідро-пневматичної сівалки. Аналіз результатів показав, що пропуск насіння склав 2,55 \% за визначальних фракторів в межах: частота обертання вала 18,42...19,17 c c $^{-1}$ жорсткість пружини державки $541 \ldots 547$ Н/м, швидкість потоку повітря, який направляється в насіннєвий ящик 5,78...6,15 м/с. Запропонована технологія забезпечує уникнення пропусків насіння та пошкодження ростків в процесі посіву овочів гідро-пневматичним висівним апаратом, що забеспечує економію й отримання ранньої продукції.
\end{abstract}

Ключові слова: гідро-пневматичний спосіб; висівний апарат; пророщене насіння; водонасіннєва рідина; сила адгезії.

Постановка проблеми. В Україні посів насіння овочів здійснюється рядковим способом механічними сівалками вітчизняного виробництва СТВТ-4, СОН-4-2,СОT-4/2 і пневмомеханічними - СУПО-8, КЛЕН та закордонними - Gaspardo-Olimpia, Gaspardo-Orietta, Colibra. Відомі сівалки використовують для посіву насіння овочів при робочій швидкості $5 \ldots 8$ км/год, де диски і осередки відповідають розмірам зерен. Висів відбувається із заданою кількістю насіння на гектар та повною рівномірністю розміщення в рядку та лише за сприятливих умов, що здатні забезпечити потрібну густоту рослин. Нажаль, вони не пристосовані для посіву пророщеного легковагового насіння.

Аналіз останніх досліджень. Розробці апарату для висіву пророщеного насіння присвячені дослідження Мельника В.І., Пастухова В.І., Бакуми М.В., Манчинського Ю.О., Бойко В.Б., Булгакова В.М. Пилипаки С.Ф., Черкащенко Г.М., Ольховського М.Ф., Клімчука О.Д., Труфляка Є.В., Яркіна Д.С., Дешко В.І., Коновал О.О., Кузьменко Л.І., Ящук Д.А. та інших науковців [1-9].
Існує ряд висівних апаратів, які використовуються в агропромисловому комплексі для якісного висівання несипучого насіння, які мають ряд недоліків, що пов'язані, насамперед, з механічними пошкодженнями насіння та ростків, та залежністю норми висіву від швидкості руху. Також, одним із недоліків пневматичного висівного апарату є відсутність ізольованої камери, що веде до підвищених витрат повітря. В результаті чого висів насіння проходить за більшого ніж потрібно тиску, тому дозування висівання може бути низько ефективним [1-9]. Також виникає потреба у створенні комбінованих посівних машин для скорочення розриву в часі між процесами обробітку насіння та його висівом у грунт.

Мета досліджень. Проведений літературний огляд показав, що немає універсального апарату для висіву пророщеного легковагового насіння овочів із заданою відстанню між ними та мінімізацією пошкодження насіння й їх ростків.

Підвищення якості процесу висіву легковагового насіння можливе при удосконаленні гідропневматичного апарату. У модернізовану пнев- 
мосівалку марки СПЧ-6М пропонується вбудувати пристрої для покращення якості посіву пророщеного насіння, а саме: технічну система для знезараження насіння, пристрій для обробки насіння випромінюванням надвисокої частоти, пристрій для підрахунку кількості листочків пророщеної культури та підрахунку кількості насінин. Крім того, модернізувати конструкцію сошників, які забезпечують рівномірність висіву пророщеного насіння гідро-пневматичним способом [10].

Результати досліджень. Для досліджень було вибране насіння огірків сортів Фенікс-640 та Дальновосточний-27, кабачків Садко $\mathrm{F}-1$, які $\epsilon$ стійкими до засухи, серед яких відбирали крупне, повновагомі, не пошкоджене. Посівний матеріал по 100 насінин кожного сорту замочуювали у 3відсотковому розчині кухонної солі, змішували і витримували 5-7 хвилин. Проводилося прогрівання за допомогою опалювального приладу протягом доби для забезпечення наближення умов пророщування до виробничих, потім замочувалося насіння повторно у воді та витримувалося 2...3 години до повного набухання. Дослідження виконувались за змінної температури пророщування $25 \ldots 38^{\circ} \mathrm{C}$ з фіксацією часу розвитку ростка та його розмірів.

Під час експериментів досліджувались фрізикомеханічні властивості пророщеного насіння овочів, а саме: визначення коефіцієнтів тертя насіння та зчеплення з робочою поверхнею ложки та параметри насіння. У процесі роботи гідро-пневматичного висівного апарату тертя виникає між насінням та стінками насіннєвого ящика, поверхнями робочих і допоміжних органів, а також тертя спокою насіння на внутрішній поверхні ложки під час його транспортування до висівного вікна. Показники тертя змінюються під впливом факторів: вологість зразка, стан робочої поверхні. Матеріалами дослідних поверхонь виступали найбільш поширені у сівалках: сталь, гума, полівінілхлорид і фторопласт. Показники тертя руху визначались на приладі академіка В.А. Желіговського.

Результати експериментальних вимірювань коефіцієнтів тертя представлено в таблиці 1. Побудовані графрічні залежності на основі цих досліджень, показали, що низьке зчеплення насіння 3 поверхнею ложки найкраще проявляється у матеріалів ПВХ і фторопласт (рис. 1). Крім того, найменше затримується на цих поверхнях насіння огірка Дальновосточний -27 (рис. 1).

Прийнявши до уваги експериментальні дослідження коефіцієнтів тертя щодо пророщеного насіння, було встановлено, що коефіцієнт зчеплення найнижчий у поверхні ПВХ, тому пропонується саме цей матеріал використовувати для виготовлення робочих поверхонь, до яких дотикається насіння (рис. 2).
Таблиця 1. Експериментальні результати вимірювання коефіцієнтів тертя

\begin{tabular}{|c|c|c|c|c|}
\hline Назва & $\sum_{\llcorner}^{\mathbb{D}}$ & 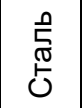 & $\stackrel{x}{\stackrel{x}{c}}$ & 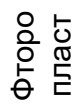 \\
\hline \multicolumn{5}{|c|}{ Коефіцієнти тертя спокою } \\
\hline Огірок Дальновосточний-27 & 0,58 & 0,42 & 0,29 & 0,32 \\
\hline Огірок Фенікс-640 & 0,67 & 0,45 & 0,39 & 0,45 \\
\hline Кабачок Садко F-1 & 0,60 & 0,65 & 0,41 & 0,45 \\
\hline \multicolumn{5}{|c|}{$\begin{array}{c}\text { Коефріцієнти тертя } \\
\text { ковзання пророщеного насіння }\end{array}$} \\
\hline Огірок Дальновосточний-27 & 0,35 & 0,22 & 0,13 & 0,16 \\
\hline Огірок Фенікс-640 & 0,43 & 0,20 & 0,19 & 0,20 \\
\hline Кабачок Садко F-1 & 0,42 & 0,45 & 0,20 & 0,23 \\
\hline
\end{tabular}

Крім того, порівнюючи представлені графічні залежності спостерігається значне зниження коефіцієнту тертя при використанні пророщеного насіння у якості висівного матеріалу.

В цілому ефрективність використання пророщеного насіння для висіву лише за коефіцієнтом тертя $€$ високою для ПВХ поверхонь та фрторопластів, що в середньому становить поліпшення якості висіву у 2 рази.

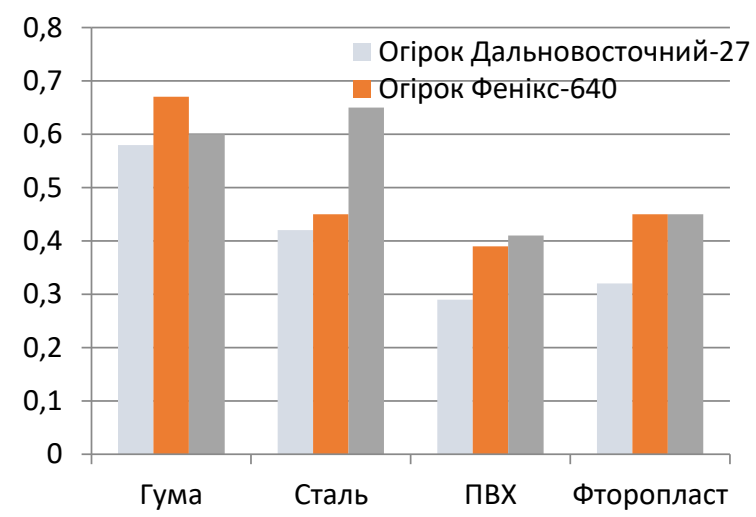

Рис. 1. Коефріцієнти тертя спокою для дослідного насіння

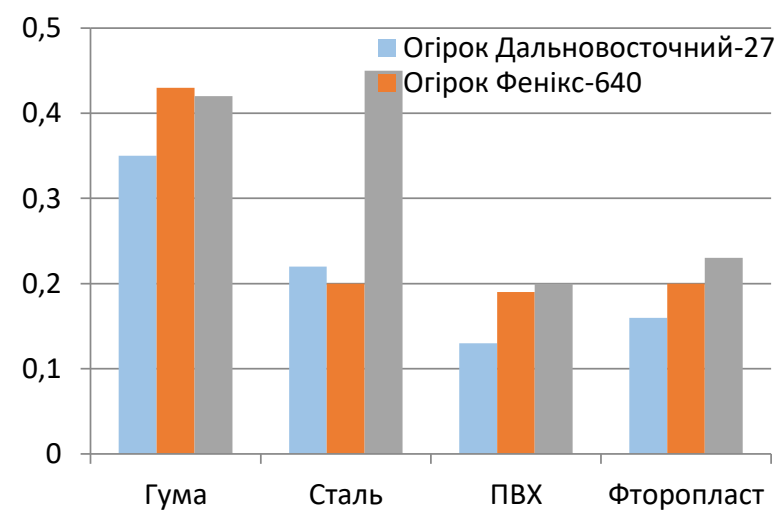

Рис. 2. Коефіцієнти тертя ковзання пророщеного дослідного насіння 
У дослідженнях фрізико-механічних властивостей пророщеного насіння овочів визначались фрорма, розміри і маса, які впливають на процес заповнення ложок апарата насінням і викидання насіння у висівне вікно. Розміри визначалися до 0,05 мм, маса за допомогою електронних терезів для сухого насіння та в результаті його набухання і пророщування.

За методикою визначення коефіцієнту зчеплення насіння з поверхнею ложки за допомогою електронного динамометра проводили вимірювання сили адгезії між двома пластинами, на одній з яких наклеєно насіння овочів, а інша з бавовняною тканиною притиснута до неї. Через добу за оптимальних умов пророщення проводились повторні вимірювання сили адгезії та визначались графічні залежності. Наявність зчеплення забезпечує також водо-насіннєва рідина, якою змочують насіння в процесі висіву. Для визначення наявності крохмалю в цій рідині до неї додають 5-відсотковий спиртовий розчин йоду. Наявність синього кольору свідчить про присутність крохмалю у розчині. В'язкість водо-насіннєвої рідини вимірювалася візкозиметром з метою визначення оптимального показника ії̈ зчеплення 3 насінням у ложці.

Для проведення польових досліджень використовували гідро-пневматичний висівний апарат, в насіннєвий ящик якого вертикально вставлений диск, на якому закріплені державки з ложками, куди завантажується пророщене насіння овочів разом з водою. Апарат має уловлювач, нижня частина якого $є$ висівним вікном, де компресором нагнітається повітря і подається до насіннєвого ящика, чим забезпечується подача водонасіннєвої рідини в одному напрямку. Спочатку ложка входить у водо-насіннєву рідину, що сприяє затягуванню насіння та перекриванню отвору. В результаті чого тиск під насінням зменшується, що спричиняє переорієнтацію насіння в ложці та надійно його утримує. На ложку діє сила инерції, яка за допомогою пружини викидає до уловлювача насіння, що направляється у висівне вікно з визначеним інтервалом, в результаті чого насіння надходить по насіннєвопроводу в борозну, виконану сошником.

В експериментах використовувалось матричне планування, де були визначені три найвпливовіші на висів змінні фактори: $x_{1}$ - частота обертання вала, $\mathrm{c}^{-1} ; x_{2}$ - жорсткість пружини державки, Н/м; $x_{3}$ - швидкість потоку повітря, який направляється в насіннєвий ящик, м/с. Вихідним показником було обрано пропуск насіння у відсотках. У результаті математичних перетворень встановлено оптимальні значення фікторів $x_{1}=17.97, x_{2}=553, x_{3}=6,12$. Адекватність математичних моделей перевірялася за критерієм Фішера. За результатами досліджень відповідно рівнянь регресії побудовано графрічні зображення поверхонь в програмному продукті Statistica (рис. 3). Аналіз результатів показав, що пропуск насіння склав 2,55 \% за значень фракторів:

$$
\begin{gathered}
x_{1}=18.42 \ldots 19,17 \mathrm{c}^{-1}, \\
x_{2}=541 \ldots 547 \mathrm{H} / \mathrm{M}, \\
x_{3}=5.78 \ldots 6,15 \mathrm{M} / \mathrm{c} .
\end{gathered}
$$

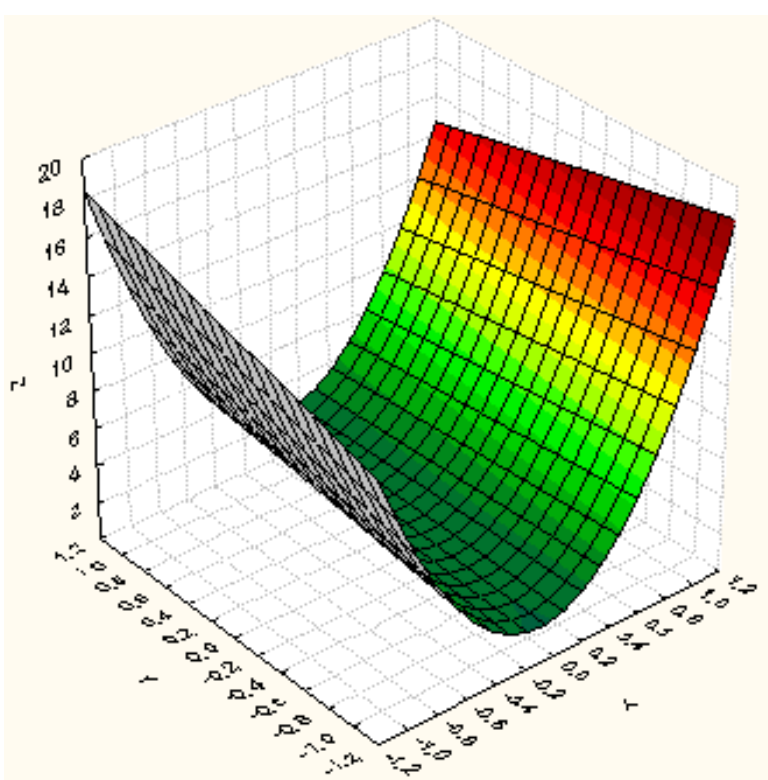

Рис. 3. Графрічне зображення поверхні взаємодії змінних фракторів

Проведений розрахунок економічної ефективності за стандартною методикою. Приріст чистого прибутку на 1 га посівів склав для насіння огірків Дальновосточний-27 - 707,00 грн., огірків Фенікс640 - 4730,00 грн., кабачків Садко F-1 - 4060,00 грн.

Висновок. Встановлено, що існуючі висівні апарати у процесі висіву пророщеного легковагового насіння овочів не забезпечують ефективного якісного висіву внаслідок налипання частини насіння на поверхнях робочих органів. Запропонований принцип обробки насіння у модернізованій гідро-пневматичній сівалці дозволяє оптимізувати процес висіву насіння та забезпечити високоякісний висів насіння у ґрунт з уникненням пропусків насіння. Для досягнення цього проводиться зменшення сили адгезії шляхом зміни швидкості подачі повітря в ящик, зокрема, для пророщеного насіння огірків швидкість подачі повітря становить 2,773,15 м/с, кабачків - 3,35 м/с. Результати польових досліджень показали, що пророщене насіння, яке попередньо замочене водо-насіннєвою рідиною, зійшло з глибини посіву 8 см через 5 днів зі схожістю $98 \%$, а сухе непророщене - 3 глибини 8 см через 14 днів зі схожістю 50\%.

Перевагою запропонованої технології $\epsilon$ уникнення пропусків насіння та пошкодження ростків в процесі посіву овочів висівним апа- 
ратом, що забеспечує економію легковагового насіння й отримання ранньої продукції. Результати проведених лабораторно-польових досліджень підтвердили теоретичне обґрунтування доцільності використання удосконаленої гідропневматичної сівалки.

\section{Література:}

1. Пастухов В. І. Перспективи розвитку промислового виробництва овочів в Харківському регіоні. Вісник Харківського національного технічного університету сільського господарства імені Петра Василенка. Харків, 2012. Вип. 124. Т. 1. C. 221-232.

2. Мельник В., Циганенко М., Аникеев А., Сыровицкий К. Экономическая эфффективность элементов системы точного земледелия. Motrol. Commission of Motorization and Energetics in Agriculture, 2015. Vol.17. № 7. P. 61-66.

3. Ящук Д.А., Ольховський Н.Ф., Бакум М. В., Манчинський Ю.О. До обґрунтуванням нового способу сівби насіння овочевих культур. Вісник ХНТУСГ. Вип. №75. Том1. Харків, 2008. C. 174-178.

4. Лазаренко Я.С., Цепляев А. Н. Совершенствование посева проросшими семенами овощных культур. Наука и молодежь: новые идеи и решения : Материалы IV Международной научно-практической конференции молодых исследователей, 26-28 апреля 2010 г. Волгоград. Часть 1. С. 187-188.

5. Цепляев A.H., Шапров М.H., Мартынов И.С., Абезин Д.А. Инновационные технологии и средства механизации посева семян бахчевых культур. Известия Нижневолжского агроуниверситетского комплекса: наука и высшее профрессиональное образование, 2009. № 2. C. 88-94.

6. Абезин В.Г., Цепляев А.Н. Высевающие аппараты для точного высева проращенных семян овощных и бахчевых культур. Известия Нижневолжского агроуниверситетского комплекса : наука и высшее профессиональное образование. 2010. № 4 (20). С. 149-157.

7. Asagi N., Ueno H., Sekiya H., Ogiwara H. Establishment of rice seedlings by direct sowing multiple seed pellets on paddy soil covered with legume living mulch. Plant Production Science, 2008. Vol.11. № 3. P. 361-365.

8. Taylor A.G., Eckenrode C.J. and Straub R.W. Seed treatments for onions: Challenges and progress. HortScience, 2001. Vol. 36(2). P. 199-205.

9. Garrett R.E., Shafii S., Upadhyaya S.K. Encapsulation of seeds in gel by impact. Applied Engineering in Agriculture, 1994. Vol. 10(2). P. 183-187.

10. Прасолов Є.Я., Рижкова Т.Ю., Величко К.С. Удосконалення гідро-пневматичного висівного апарату. Технології і засоби механізації сільськогосподарського виробництва : матеріали Всеукраїнської науково-практичної конференції молодих вчених, студентів та аспірантів, 11-14 травня 2020 р. Полтава, 2020. С.76-77.

\section{References}

1. Pastuxov V. I. Perspekty`vy` rozvy`tku promy`slovogo vy`robny`cztva ovochiv v Xarkivs`komu regioni. Visny`k Xarkivs`kogo nacional'nogo texnichnogo universy`tetu sil’s`kogo gospodarstva imeni Petra Vasy`lenka. Xarkiv, 2012. Vy’p. 124. T. 1. S. 221-232.

2. Melnik V., Ciganenko M., Anikeev A., Syrovickij K. Jekonomicheskaja jeffektivnost jelementov sistemy tochnogo zemledelija. Motrol. Commission of Motorization and Energetics in Agriculture, 2015. Vol.17. № 7. S. 61-66.

3. Yashhuk D.A., Ol’xovs`ky j N.F., Bakum M. V., Manchy`ns`ky`j Yu.O. Do obg`runtuvannyam novogo sposobu sivby nasinnya ovochevy`x kul tur. Visny`k XNTUSG. Vy’p. \#75. Tom1. Xarkiv, 2008. S.174-178.

4. Lazarenko Ja.S., Cepljaev A.N. Sovershenstvovanie poseva prorosshimi semenami ovoshhnyh kul'tur. Nauka i molodezh': novye idei i reshenija : Materialy IV Mezhdunarodnoj nauchno-prakticheskoj konferencii molodyh issledovatelej, 26-28 aprelja 2010 g. Volgograd. Chast' 1. S. 187-188.

5. Cepljaev A.N., Shaprov M.N., Martynov I.S., Abezin D.A. Innovacionnye tehnologii i sredstva mehanizacii poseva semjan bahchevyh kul'tur. Izvestija Nizhnevolzhskogo agrouniversitetskogo kompleksa: nauka i vysshee professional'noe obrazovanie, 2009. № 2. S. 88-94.

6. Abezin V.G., Cepljaev A.N. Vysevajushhie apparaty dlja tochnogo vyseva prorashhennyh semjan ovoshhnyh i bahchevyh kul'tur. Izvestija Nizhnevolzhskogo agrouniversitetskogo kompleksa : nauka i vysshee professional'noe obrazovanie, 2010. № 4 (20). S. 149-157.

7. Asagi N., Ueno H., Sekiya H., Ogiwara H. Establishment of rice seedlings by direct sowing multiple seed pellets on paddy soil covered with legume living mulch. Plant Production Science, 2008. Vol.11. № 3. P. 361-365.

8. Taylor A.G., Eckenrode C.J. and Straub R.W. Seed treatments for onions: Challenges and progress. HortScience, 2001. Vol. 36(2). P. 199-205.

9. Garrett R.E., Shafii S., Upadhyaya S.K. Encapsulation of seeds in gel by impact. Applied Engineering in Agriculture, 1994. Vol. 10(2). P. 183-187.

10. Prasolov Ye.Ya., Ry`zhkova T.Yu., Vely`chko K.S. Udoskonalennya gidro-pnevmaty chnogo vy`sivnogo aparatu. Texnologiyi i zasoby' mexanizaciyi sil’s`kogospodars`kogo vy`robny`cztva: materialy' Vseukrayins 'koyi naukovo-prakty”chnoyi konferenciyi molody $x$ vcheny $x$, studentiv ta aspirantiv, 11-14 travnya 2020 r. Poltava, 2020. S.76-77. 


\title{
Аннотация
}

\section{Особенности модернизации гидро-пневматического висевающего аппарата}

\author{
Е.Я. Прасолов, Т.Ю. Рыжкова, К.С. Величко
}

Известные конструкции гидравлических и пневматических посевных аппаратов ведут к травмированию семян и их ростков во время посева. В модернизированную гидро-пневматическую сеялку предлагается встроить устройства для улучшения качества высева семян. В неё входят: система для обеззараживания семян, устройство для обработки семян излучениями сверхвысокой частоты, устройство для подсчета количества листочков пророщенных семян и подсчета количества семян. Проведено модернизацию конструкции сошников, которые обеспечивают равномерность высева пророщенных семян гидро-пневматическим способом.

Проводились исследования физико-механических свойств семян овощей. Показано, что коэффициент трения семян об рабочие поверхности ложки и стенки семенного ящика, а также других дополнительных органов влияет на качество высева семян, количество пропусков и повреждения ростков в процессе высева. Определено, что наименьшее трение семян с рабочими поверхностями у материалов ПВХ и фрторопластов. Снижение коэффициента трения при использовании пророщенных семян как высевного материала повышает качество высева семян в сравнении с непророщенными семенами в среднем на 48 \%. Использование предложенной водно-семенной жидкости, которой смачивают семена в процессе высева, повышает качество затягивания ложкой семян. Это способствует переориентации семян в ложке и обеспечению их надежной фиксации.

По трём фракторам определены оптимальные параметры работы гидро-пневматической сеялки. Анализ результатов показал, что пропуск семян составляет 2,55 \% по определяющим фракторам в диапазоне: частота оборотов вала 18,42...19,17 $\mathrm{c}^{-1}$, жесткость пружины державки $541 \ldots 547$ Н/м, скорость потока воздуха, который направляется в семенной ящик 5,78...6,15 м/с. Предложена технология исключает пропуски семян и повреждения ростков в процессе посева овощей гидропневматическим висевным аппаратом, что обеспечивает экономию и получение ранней продукции

Ключевые слова: гидро-пневматический способ; висевающий аппарат; проросшие семена; водносеменная жидкость; сила адгезии.

\begin{abstract}

\section{Features of modernization hydro-pneumatic sowing machine}

\section{E.Ya. Prasolov, T.Yu. Ryzhkova, K.S. Velichko}

Well-known hydraulic and pneumatic sowing machine designs cause damage to seeds and their sprouts during sowing. The modernised hydro-pneumatic sowing machine is designed to incorporate devices to improve seed quality. It includes: a system for disinfecting seeds, a device for treating seeds with ultra-high frequency radiation, a device for counting germinated seed leaves and counting the number of seeds. The coulter structure was modernized which ensure that germinated seeds are evenly sown using the hydro-pneumatic method.

Researches were conducted on the physical and mechanical properties of vegetable seeds. The friction coefficient of the seed against the working surfaces of the spoon and the wall of the seed box and other additional organs affects the quality of seed sowing, the number of passes and sprouts damaged during sowing. The lowest friction on work surfaces made of PVC and PTFE materials was determined. The friction coefficient is reduced by using germinated seeds as sowing material, which results in an average increase of 48 $\%$ in the quality of sowing compared to non-productive seeds. The use of aqueous seed fluid increases the quality of spoon-tightening the seeds. This aqueous-seed fluid soaks the seeds during the sowing process. This promotes the reorientation of the seeds in the spoon and ensures that they are firmly anchored.

The optimum performance parameters of the hydro-pneumatic seeder are determined by three factors. The results showed a seed pass of $2.55 \%$ according to the determining factors in the range: shaft rotation frequency $18.42 \ldots 19.17 \mathrm{~s}^{-1}$, spring rigidity for holder $541 \ldots 547 \mathrm{~N} / \mathrm{m}$, airflow rate directed to the seed box $5.78 \ldots 6.15 \mathrm{~m} / \mathrm{s}$. This technology eliminates skipping seeds and avoids damage to the sprouts during the sowing of vegetables with a hydro-pneumatic sowing machine, it is an economical process and makes it possible to obtain early products.
\end{abstract}

Keywords: hydro-pneumatic way; sowing machine; germinated seeds; aqueous-seed fluid; adhesive strength.

Бібліографічне посилання/ Bibliography citation: Harvard

Prasolov, E. Y., Ryzhkova, T. Y. and Velichko, K. S. (2020) 'Features of modernization hydro-pneumatic sowing machine', Engineering of nature management, (3(17), pp. 65 - 69.

Подано до редакції / Received: 02.09.2020 